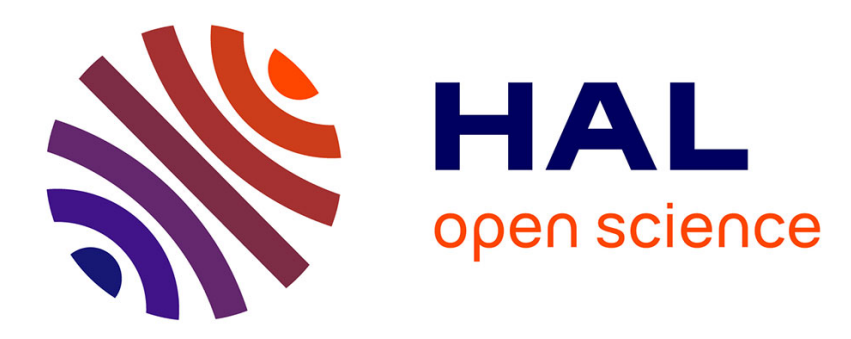

\title{
MATERIAL REMOVAL PROCESSING WITH HIGH-POWER LASERS
}

\author{
H. Tönshoff, M. Stürmer
}

\section{To cite this version:}

H. Tönshoff, M. Stürmer. MATERIAL REMOVAL PROCESSING WITH HIGH-POWER LASERS. Journal de Physique IV Proceedings, 1991, 01 (C7), pp.C7-134-C7-134. 10.1051/jp4:1991730 . jpa00250933

\section{HAL Id: jpa-00250933 https://hal.science/jpa-00250933}

Submitted on 1 Jan 1991

HAL is a multi-disciplinary open access archive for the deposit and dissemination of scientific research documents, whether they are published or not. The documents may come from teaching and research institutions in France or abroad, or from public or private research centers.
L'archive ouverte pluridisciplinaire HAL, est destinée au dépôt et à la diffusion de documents scientifiques de niveau recherche, publiés ou non, émanant des établissements d'enseignement et de recherche français ou étrangers, des laboratoires publics ou privés. 


\section{MATERIAL REMOVAL PROCESSING WITH HIGH-POWER LASERS}

H.K. TÖNSHOFF and M. STÜRMER

Laser Zentrum Hannover, Department of Production Technology

Based upon the well-established manufacturing processes lasercutting and -welding, new applicability in the field of laser material removal is now opened up. One aspect for accurate workpiece geometries is the so called laser-milling-technique. In comparison with milling and EDM, this tooling method is able to machine hard and abrasive materials both metals and nonmetals (e.g. ceramics, quartz glass) as well as plastics without contact. It is possible to produce and refinish NC controlled forms.

This paper deals with the basics and the state-of-the-art of laser-milling. After a review of investigation results concerning the influence of laser source-, beam- and processparameters the removal strategy will be shown. The workpiece properties HAZ, hardness, oxide layers and cracks are of particular importance. Process improvements like material remelting for a glazed surface finish work with an additional data base, and an online process-control consisting of surface and distance measurement can lead to better results. 